\title{
Physiological and biochemical responses of Fibigia triquetra (DC.) Boiss. to osmotic stress
}

\author{
Valerija Vujčić*, Sandra Radić Brkanac \\ Department of Biology, Faculty of Science, University of Zagreb, Rooseveltov trg 6, \\ HR-10000 Zagreb, Croatia
}

\begin{abstract}
Water deficit in the soil leads to osmotic stress in plants. The type of stress affects plant water relations, osmolyte accumulation and oxidative stress balance. The present study aimed to investigate the effects of osmotic stress on the Croatian perennial species Fibigia triquetra (DC.) Boiss, adapted to a hot and dry habitat. Plants grown in culture conditions were subjected to isoosmotic concentrations of mannitol and polyethylene glycol (PEG) and certain physiological and oxidative stress parameters were analyzed during a period of 14 days. Dry weight and proline content in Fibigia triquetra shoots increased in response to osmotic stress while the relative water content decreased. After an initial rise, chlorophyll and carotenoid levels in treated plants dropped to untreated plant levels. Oxidative damage to proteins and especially to lipids was evident upon PEG-induced osmotic stress. Superoxide dismutase and ascorbate peroxidase appear to play an essential protective role in stressed plants. Regardless of the osmotic agent, accumulation of heatshock proteins of $70 \mathrm{kDa}$ was noticed under osmotic stress. The tolerance of the plant species to osmotic stress seems to be associated with increased capacity of the antioxidative system and efficient photoprotective system.
\end{abstract}

Keywords: antioxidative enzymes, lipid peroxidation, mannitol, osmotic stress, oxidative damage, polyethylene glycol, proline, stress proteins

\begin{abstract}
Abbreviations: APOX - ascorbate peroxidase, CAT - catalase, DW - dry weight, FW fresh weight, MDA - malondialdehyde, PAGE - polyacrylamide gel electrophoresis, PEG polyethylene glycol, POX - pyrogallol peroxidase, RWC - relative water content, SOD superoxide dismutase
\end{abstract}

\section{Introduction}

Drought is one of the most common abiotic stressors limiting plant productivity. Under such stress, water deficit in plant tissue develops and the photosynthetic rate decreases due to stomatal closure or metabolic impairment (REDDY et al. 2004). Plants have evolved differ-

* Corresponding author, e-mail: vvujcic@biol.pmf.hr 
ent mechanisms to limit water loss, including adaptations at morphological and physiological levels - thick cuticle, sunken stomata, reduced leaf surface area, shoot growth inhibition, enhanced root growth, changes in carbon metabolism and synthesis of compatible solutes such as proline, glycine betaine, various sugars and polyols (XIONG and ZHU 2002, Chaves et al. 2009). Accumulation of proline is a common metabolic response of plants to various abiotic stress conditions including water deficit and salt stress (BARTELS and SUNKAR 2005, HAYAT et al. 2012). Aside from acting as an osmoprotectant, proline has been reported to play an important role in the removal of reactive oxygen species (ROS), maintaining protein stability and the regulation of $\mathrm{pH}$ in the cytoplasm (HАYAT et al. 2012).

Inhibition of $\mathrm{CO}_{2}$ assimilation coupled with changes in photosystem activities and photosynthetic electron transport capacity results in increased generation of ROS which may cause damage to membrane lipids and proteins and inactivate SH-containing enzymes (REDDY et al. 2004). This enhanced ROS production is however kept under tight control by a versatile antioxidant system that includes enzymes such as superoxide dismutase (SOD), catalase (CAT) and ascorbate peroxidase (APX) and low molecular weight antioxidants such as ascorbic acid, tocopherol, carotenoids and other (CRUz De CARVALHo 2008). In addition to the activation of oxidative stress protection mechanisms, the combined effects of multiple stress factors (drought, extreme temperatures, increased salinity etc.) often induce synthesis of various stress proteins such as heat-shock proteins (HSPs) involved in the folding of nascent proteins and the refolding of denatured proteins. Among HSPs, the stressinducible heat shock protein $70 \mathrm{kDa}$ (HSP70) has been proposed as a biomarker for monitoring environmental stressors (WANG et al. 2004).

Fibigia triquetra (DC.) Boiss. is a Croatian rare stenoendemic plant species growing on sunny and dry habitats of calcareous rocks and thus often exposed to water deficit (PEVALEKKozlina et al. 1997). Because of the natural habitat of F. triquetra, we assume that the plant has developed tolerance to drought and high temperatures as well as to oxidative stress. Osmotic stress in experimental conditions is often simulated by using polyethylene glycol (PEG, non-ionic-impermeable osmoticum) and mannitol (non-ionic-permeable osmoticum). Since mannitol partially enters the cell, the use of high molecular weight PEG (6000 or 8000) is recommended under laboratory conditions (VERSLUES et al. 2006). Several studies carried out with different osmotic agents correlated efficient antioxidant defense with tolerance mechanisms (RADIĆ et al. 2006, 2013). We hypothesized that F. triquetra tolerance to osmotic stress could be associated with induction of the antioxidative system and HSP70 stress protein as well as effective osmoregulation mechanisms. Hence, this study reports on: 1) a comparative analysis of the changes in the activities of antioxidative enzymes, 2) analysis of proline (compatible solute and antioxidant), and 3) a possible accumulation of HSP70 upon PEG- and mannitol-induced osmotic stress.

\section{Material and methods}

\section{Plant material and osmotic treatments}

F. triquetra seeds were collected from their natural habitat. The sterilized seeds were inoculated in test tubes filled with $15 \mathrm{~mL}$ of MS $1 / 2$ medium containing $0.1 \mathrm{~g} \mathrm{~L}^{-1}$ myoinositol (Sigma-Aldrich), $0.1 \mathrm{mg} \mathrm{L}^{-1}$ thiamine $\times \mathrm{HCl}\left(\right.$ Sigma-Aldrich), $0.5 \mathrm{mg} \mathrm{L}^{-1}$ pyridoxine $\times \mathrm{HCl}$ (Sigma-Aldrich), $0.5 \mathrm{mg} \mathrm{L}^{-1}$ nicotinic acid (Sigma-Aldrich), $2.9 \mu \mathrm{M}$ gibberellic acid $\left(\mathrm{GA}_{3}\right.$; 
Sigma-Aldrich), $0.5 \mu \mathrm{M}$ 6-benzylaminopurine (BA; Sigma-Aldrich), $30 \mathrm{~g} \mathrm{~L}^{-1}$ sucrose (Kemika) and $8 \mathrm{~g} \mathrm{~L}^{-1}$ agar (Sigma-Aldrich) (Murashige and Skoog 1962, Pevalek-Kozlina et al. 1997). The $\mathrm{pH}$ value of nutrient medium was adjusted to 7 with $0.1 \mathrm{M} \mathrm{KOH}$ (Kemika) and the medium was autoclaved at $118 \mathrm{kPa}$ and $120^{\circ} \mathrm{C}$ for $20 \mathrm{~min}$. The cultures were grown under a $16 \mathrm{~h}$ photoperiod of fluorescent light $\left(80 \mu \mathrm{E} \mathrm{m}^{-2} \mathrm{~s}^{-1}\right)$ at $24 \pm 2{ }^{\circ} \mathrm{C}$. Four-week old plants were subcultured to liquid MS $1 / 2$ medium and, following root initiation, were transferred to medium of the same composition supplemented with mannitol (Sigma-Aldrich) or PEG (Sigma-Aldrich). Except for the control medium, osmotica were added to the medium as $51 \mathrm{~g} \mathrm{~L}^{-1}$ mannitol or $168 \mathrm{~g} \mathrm{~L}^{-1}$ PEG 6000 corresponding to $-1.0 \mathrm{MPa}$ in both cases. The water potentials of nutrient solutions were determined by a cryoscopic osmometer (Knauer). Plants were exposed to mannitol- and PEG-mediated osmotic stress for a period of 14 days. Shoot samples for all analyses were collected after 1, 7 and 14 days of experiment.

\section{Growth parameters}

Dry weight (DW) was measured after oven drying of the samples at $70{ }^{\circ} \mathrm{C}$ for $48 \mathrm{~h}$. Relative water content (RWC) was calculated as: $\mathrm{RWC}(\%)=(\mathrm{FW}-\mathrm{DW}) / \mathrm{FW} \times 100$ where FW denotes fresh weight. Prior to determination of fresh weight, shoots were washed with distilled water and dried with towels.

\section{Proline content}

Free proline content was measured by the method of BATES et al. (1973). Plant tissue was homogenized in 3\% (w/v) sulphosalycylic acid (Sigma-Aldrich) and centrifuged at $700 \times \mathrm{g}$ for $3 \mathrm{~min}$. After addition of ninhydrin reagent (Riedel-deHaën), mixtures were heated at 100 ${ }^{\circ} \mathrm{C}$ for $1 \mathrm{~h}$ and cooled in an ice-bath. The chromophore obtained was extracted from liquid phase with toluene (Kemika) and the absorbance of the organic layer was read at $520 \mathrm{~nm}$. Proline concentration was determined from the calibration curve using L-proline as standard and expressed as nmol g- $\mathrm{FW}^{-1}$.

\section{Chlorophylls and carotenoids content}

Chlorophyll $a, b$ and total carotenoid contents were measured and calculated according to LichtentHALER (1987). In brief, fresh leaves were homogenized with $80 \%$ (v/v) cold acetone $($ Kemika), centrifuged at $5,000 \times \mathrm{g}$ for $10 \mathrm{~min}$. The absorbances of the supernatant were read at 663,646 and $470 \mathrm{~nm}$.

\section{MDA content}

Lipid peroxidation was determined by an estimation of the amount of malondialdehyde (MDA) content with the use of the thiobarbituric acid method described by HEATH and PACKER (1968). The crude extracts were mixed with $0.25 \%(\mathrm{w} / \mathrm{v})$ thiobarbituric acid (Sigma-Aldrich) solution containing 10\% (w/v) trichloroacetic acid (Sigma-Aldrich), heated at $95{ }^{\circ} \mathrm{C}$ for $30 \mathrm{~min}$ and the reaction was stopped in an ice-bath. The cooled mixtures were centrifuged at $10,000 \times \mathrm{g}$ for $10 \mathrm{~min}$ and the MDA content calculated from the absorbance at $532 \mathrm{~nm}$ (correction was done by subtracting the absorbance at $600 \mathrm{~nm}$ for non-specific turbidity) by using extinction coefficient of $155 \mathrm{mM}^{-1} \mathrm{~cm}^{-1}$. 


\section{Carbonyl groups content}

The amount of protein oxidation was estimated by the reaction of carbonyl groups $(\mathrm{C}=\mathrm{O})$ with 2, 4-dinitrophenylhydrazine (Sigma-Aldrich), as described in LEvINE et al. (1990). After the 2,4-dinitrophenylhydrazine reaction, the $\mathrm{C}=\mathrm{O}$ content was calculated by absorbance at $370 \mathrm{~nm}$, using an extinction coefficient for aliphatic hydrazones of $22 \mathrm{mM}^{-1}$ $\mathrm{cm}^{-1}$ and expressed as nmol $\mathrm{mg}^{-1}$ protein.

\section{Enzyme determinations}

Plant tissue was homogenized in $50 \mathrm{mM}$ potassium phosphate $\left(\mathrm{K}_{2} \mathrm{HPO}_{4} / \mathrm{KH}_{2} \mathrm{PO}_{4}\right)$ buffer ( $\mathrm{pH}$ 7.0) including $5 \mathrm{mM}$ sodium ascorbate (Sigma-Aldrich), $1 \mathrm{mM}$ ethylene diamine tetraacetic acid (Sigma-Aldrich) and polyvinylpolypyrrolidone (PVPP, Sigma-Aldrich). The homogenates were centrifuged (Sigma $3 \mathrm{~K} 18$ centrifuge, Germany) at 22,000 $\times \mathrm{g}$ for 20 min at $4{ }^{\circ} \mathrm{C}$. Supernatant was used for enzyme activity and protein content assays. Total soluble protein contents of the enzyme extracts were estimated according to BRADFORD (1976) using bovine albumin serum (BSA, Sigma) as standard. The activity of SOD was assayed by measuring its ability to inhibit the photochemical reduction of nitroblue tetrazolium (Sigma-Aldrich) following the method of GianNOPOLITIS and RiES (1977). One unit of SOD was taken as the volume of the enzyme extract causing 50\% inhibition of nitroblue tetrazolium reduction. CAT activity was determined by the decomposition of $\mathrm{H}_{2} \mathrm{O}_{2}$ and was measured spectrophotometrically by following the decrease in absorbance at $240 \mathrm{~nm}$ (AEBI 1984). Activity was calculated using the extinction coefficient of $0.04 \mathrm{mM}^{-1} \mathrm{~cm}^{-1}$ and $\mu \mathrm{mol}$ $\mathrm{H}_{2} \mathrm{O}_{2} \mathrm{~g}^{-1} \mathrm{FW} \mathrm{min}^{-1}$ was defined as unit of CAT. APX activity was done according to NAKANO and ASADA (1981). The ascorbate oxidation was followed at $290 \mathrm{~nm}$ and its concentration calculated using the molar extinction coefficient $\left(\varepsilon=2.8 \mathrm{mM}^{-1} \mathrm{~cm}^{-1}\right)$. Corrections were done for low, non-enzymatic oxidation of ascorbate by $\mathrm{H}_{2} \mathrm{O}_{2}$. One enzyme unit was defined as $\mu \mathrm{mol}$ oxidized ascorbate $\mathrm{g}^{-1} \mathrm{FW} \mathrm{min}^{-1}$. The activity of POX was measured by monitoring the formation of purpurogallin at $430 \mathrm{~nm}\left(\varepsilon=2.47 \mathrm{mM}^{-1} \mathrm{~cm}^{-1}\right)$ according to CHANCE and MAeHly (1955). The reaction mixture contained $50 \mathrm{mM}$ potassium phosphate buffer ( $\mathrm{pH} 7$ ), $1 \mathrm{mM} \mathrm{H} \mathrm{O}_{2}, 20 \mathrm{mM}$ pyrogallol (Sigma-Aldrich) and enzyme extract. The specific enzyme activity for all enzymes was expressed as units per mg of protein.

\section{Imunodetection of HSP70}

To analyze HSP70, plant tissue were homogenized in Tris- $\mathrm{HCl}$ extraction buffer $\mathrm{pH} 8.0$ containing 17.1\% (w/v) sucrose (Kemika), 0.1\% (w/v) ascorbic acid (Sigma-Aldrich), and $0.1 \%(\mathrm{w} / \mathrm{v})$ cysteine- hydrochloride (Sigma-Aldrich) with addition of PVPP and then centrifuged at $29,700 \times \mathrm{g}$ for $50 \mathrm{~min}$. Total protein concentration in the supernatant was determined according to BRADFORD (1976). Aliquots of each homogenate were mixed with corresponding volumes of denaturing $0.065 \mathrm{M}$ Tris- $\mathrm{HCl}$ buffer containing $6 \%(\mathrm{w} / \mathrm{v})$ sodium dodecyl sulfate (SDS, Sigma-Aldrich), $6 \%$ (v/v) $\beta$-mercaptoethanol (Sigma-Aldrich), 30\% (v/v) glycerol, and $0.01 \%(w / v)$ of bromphenol blue (Sigma-Aldrich). The extracts were boiled for $2 \mathrm{~min}$. Constant protein weights 9 or $12 \mu \mathrm{g}$ of total protein per lane were analyzed by SDS-polyacrylamide gel electrophoresis (PAGE) (Bio-Rad, Hercules, CA, USA) and subsequent Western blotting at $60 \mathrm{~V}$ (Bio-Rad). The resolving gel was made at $10 \%$ of polyacrylamide (w/v). Standard proteins of known molecular weights (Fermentas, Glen Burnie, MD, USA) were run in the same gel. The membranes were blocked with $10 \%(\mathrm{w} / \mathrm{v})$ nonfat powdered milk solution made in phosphate-buffered saline $\left(58 \mathrm{mM} \mathrm{Na}_{2} \mathrm{HPO}_{4}, 17\right.$ 
$\left.\mathrm{mM} \mathrm{NaH} \mathrm{PO}_{4}, 68 \mathrm{mM} \mathrm{NaCl}\right) \mathrm{pH} 7.4$ containing 1\% (v/v) of Tween 20 (Sigma-Aldrich) and incubated with a rabbit monoclonal antibody raised against the pea HSP70 (diluted $1: 1000$ ) overnight at $4{ }^{\circ} \mathrm{C}$. The secondary antibody was an alkaline phosphatase-anti-rabbit IgG (Sigma- Aldrich) diluted 1:2000. The membranes were developed with nitroblue tetrazolium and 5-bromo-4-chloro-3-indolyl phosphate (Sigma-Aldrich).

\section{Statistical analysis}

Data were analyzed by one-way analysis of variance (ANOVA) using Statistica 7.1. (StatSoft, Inc.) software package, and differences between corresponding controls and exposure treatment were considered as statistically significant at $\mathrm{p}<0.05$. Each data point is the average of six replicates $(n=6)$.

\section{Results}

Exposure of $F$. triquetra to PEG-induced osmotic stress caused a significant decrease in plant water status after only one day of exposure, while after 7- and 14-day periods a significant drop in water content (between 7 and 9\% compared to control) was evident in response to both osmotica (Fig. 1 A). Mannitol induced a marked rise (a 32\% rise compared
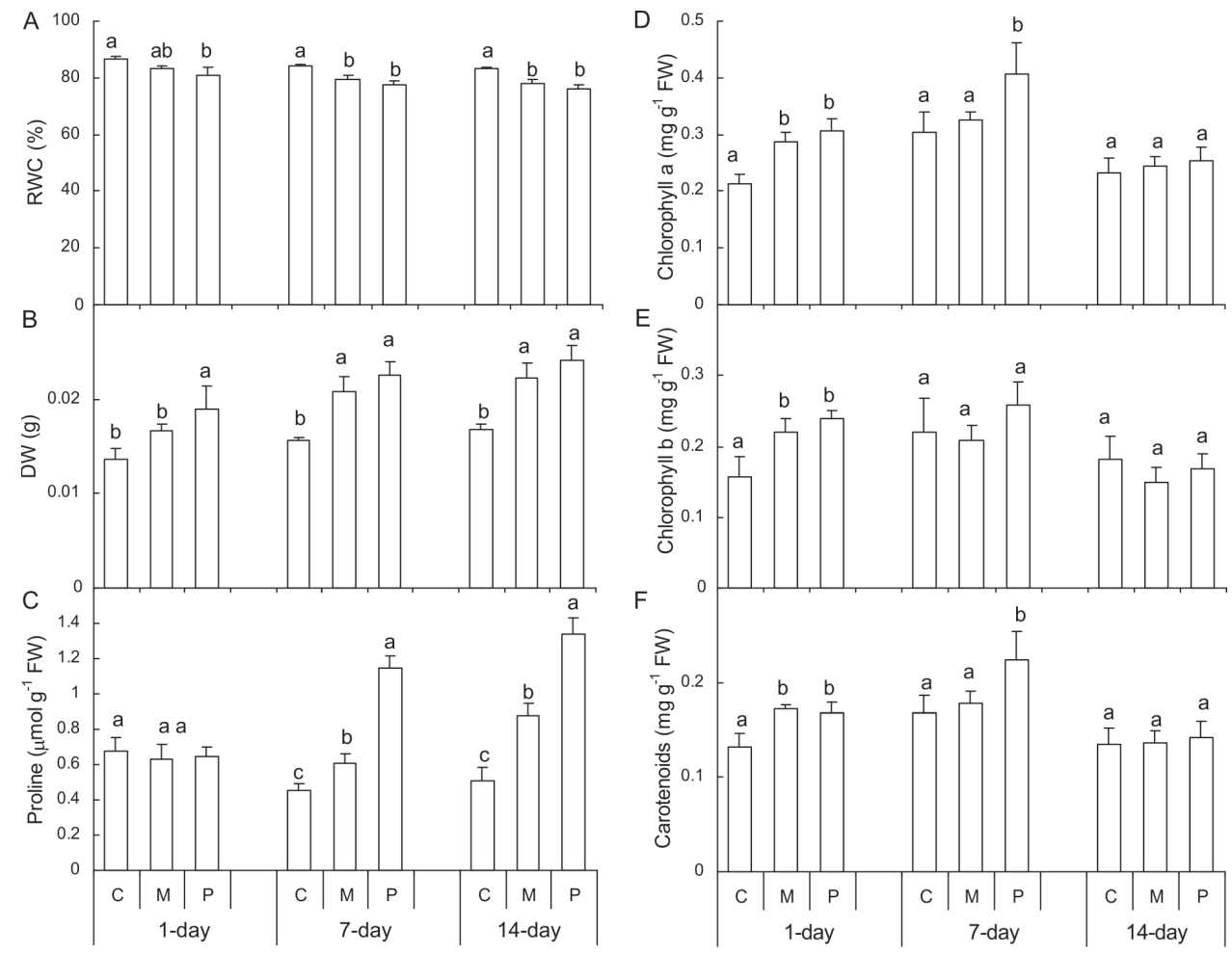

Fig. 1. Parameters: (A) RWC, (B) DW, (C) proline, (D) chlorophyll $a$, (E) chlorophyll $b$ and (F) carotenoid contents evaluated in F. triquetra plants under control conditions (C) and upon stresses caused by mannitol (M) and PEG (P) after 14- day growth period. Values are mean \pm $\mathrm{SD}$ based on six replicates. Bars with different letters are significantly different at $\mathrm{p}<0.05$. 
to control) in shoot DW after 7- and 14-day period while PEG caused more conspicuous increase of DW (over 40\% rise compared to control) which was noted even after the first day of stress (Fig. 1 B). Osmotic stress had a significant effect on proline contents following 7- and 14-day periods (Fig. $1 \mathrm{C}$ ) though PEG produced a more conspicuous rise in the amino acid content (a 2.5-fold increase compared to control) than mannitol (35 and 73\% increase compared to control following the 7- and the 14-day period, respectively).

Content of chlorophyll $a$, chlorophyll $b$ and carotenoids significantly increased after $24 \mathrm{~h}$ of plant exposure to mannitol and PEG as compared to control plants (Figs. 1 D-F). After seven days of experiment, chlorophyll and carotenoid contents under mannitol treatment were not significantly different from respective values in control plants while in plants exposed to PEG the content of these pigments was still significantly elevated. However, at the end of the experiment the contents of the studied photosynthetic pigments in osmoticstressed shoots were similar to those in control plants.

The level of lipid peroxidation, expressed as MDA content, in F. triquetra shoots sampled after $24 \mathrm{~h}$ period increased by $43 \%$ in response to mannitol (Fig. 2 A). Following longer exposure (a 7- and a 14-day growth period), the MDA content of mannitol-treated plants leveled with that of control. Unlike mannitol, PEG caused a significant rise in the
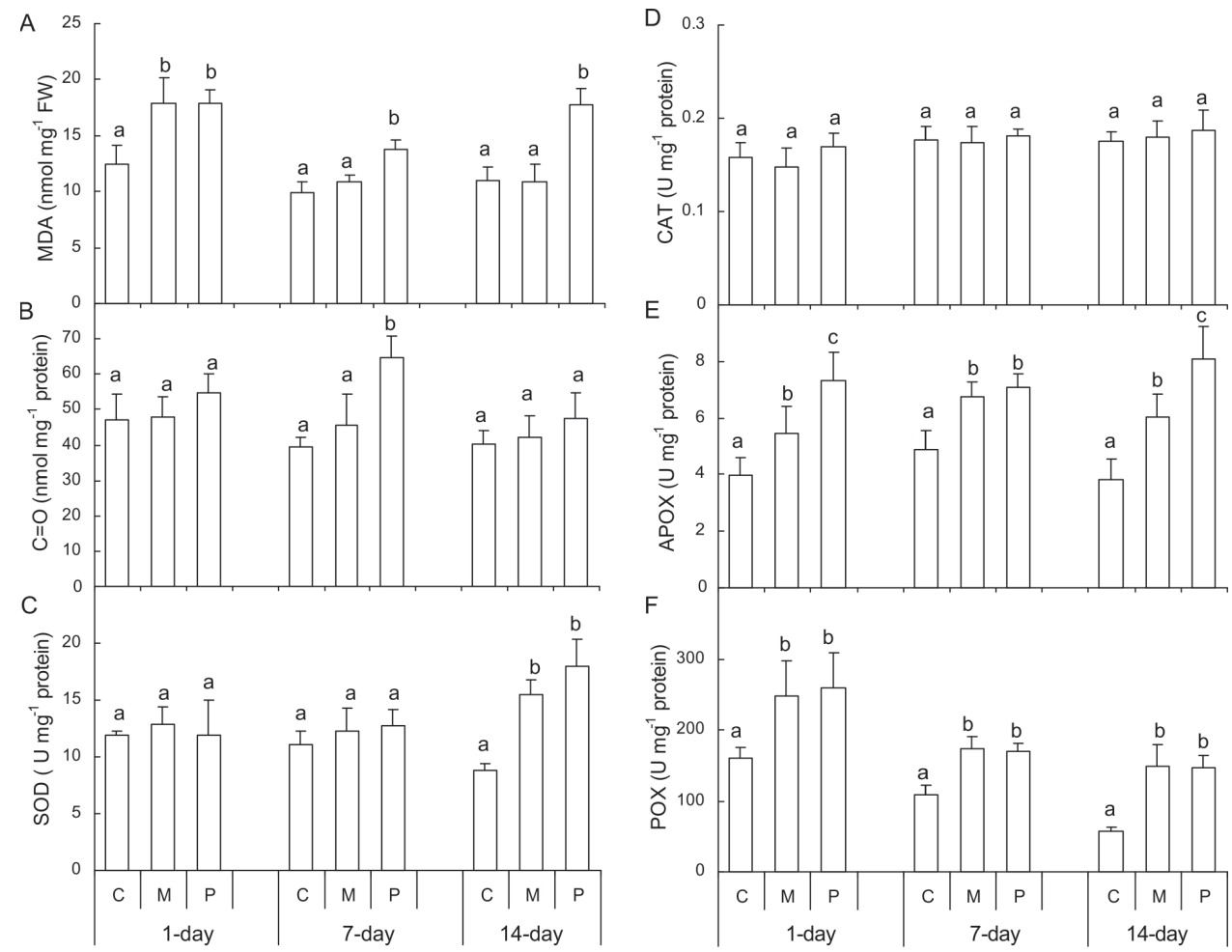

Fig. 2. Parameters: (A) MDA, (B) $\mathrm{C}=\mathrm{O}$ - carbonyl groups, (C) SOD, (D) CAT, (E) APOX and (F) POX measured in F. triquetra plants under control conditions $(\mathrm{C})$ and upon stresses caused by mannitol (M) and PEG (P) after 14-day growth period. Values are mean \pm SD based on six replicates. Bars with different letters are significantly different at $\mathrm{p}<0.05$. 
extent of lipid peroxidation during the entire experimental period (increase by $40-60 \%$, compared to control). Regarding the level of carbonyl groups, PEG induced a much stronger effect than the lower molecular weight osmoticum. Namely, the carbonyl group content of PEG-treated F. triquetra was markedly elevated compared to control plants after a 7-day period of exposure while mannitol did not show any significant effect on the parameter over the entire experimental period (Fig. 2 B).

The activity of SOD in the shoots of F. triquetra exposed to either mannitol or PEG remained unchanged after 1- and 7-day growth periods and significantly increased only at the end of the experiment (Fig. 2 C). CAT activity of $F$. triquetra shoots was not affected by either osmotica during the entire experimental period (Fig. 2 D). Regardless of the substrate used, the activity of the peroxidases (APOX and POX) of F. triquetra shoots was markedly induced by both mannitol and PEG over the entire experimental period (Figs. 2 E-F). However, after 1- and 14-day growth periods, the APOX activity of PEG-treated plants was over $30 \%$ higher than the enzyme activity of mannitol-treated plants. Under osmotic treatment, the increase of POX activity in F. triquetra shoots exceeded $50 \%$ in comparison to control after 1- and 7-day growth period. The rise in the activity of POX caused by osmotic stress was even more expressed after a 14-day growth period - both mannitol and PEG caused a 2.5-fold increase in the enzyme activity compared to control.

Proteins of plant species $F$. triquetra separated by PAGE in the denatured conditions were transferred to nitrocellulose membrane followed by immunodetection with HSP70 antibodies. After a 1-day period of exposure, the expression of the HSP70 stress protein was already stronger in treated than in control plants (Fig. 3). The protein accumulated even more in treated $F$. triquetra shoots following a longer period of exposure to mannitol and PEG.

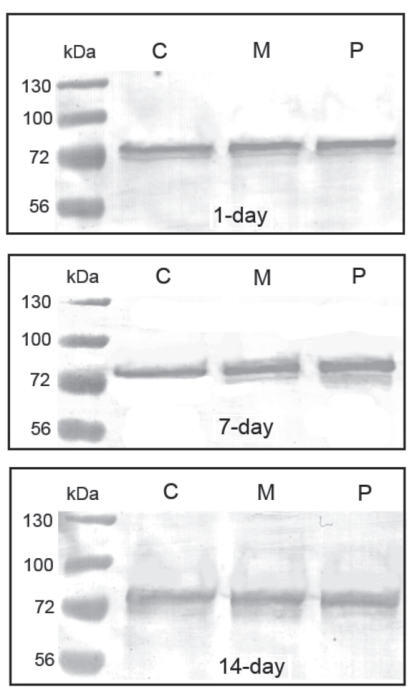

Fig. 3. Patterns of heat-shock protein of $70 \mathrm{kDa}(\mathrm{HSP} 70)$ in F. triquetra plants under control conditions (C) and upon stresses caused by mannitol (M) and PEG (P) after 1-, 7- and 14-day growth period. 


\section{Discussion}

The results presented here indicate that the use of PEG as an osmotic agent led to more severe osmotic effects in F. triquetra shoots than when mannitol was used. Although both agents produced similar effects on RWC following a longer growth period, PEG caused significant change in the parameter after only a $24 \mathrm{~h}$ period. The initially stronger effects of high-molecular-weight PEG compared to low-molecular-weight mannitol on RWC could be related to the inhibitory action of PEG on the capacity of roots to supply water to the leaves (CHAZEN et al. 1995). Stronger effects of PEG on RWC, compared to mannitol, were observed in the halophytic species Sesuvium portulacastrum exposed to osmotic stress for a 12-day period (SLAMA et al. 2007). Such effects of PEG were previously linked to greater viscosity of PEG solutions while mannitol was assumed to attenuate osmotic gradient between the medium and the cell due to uptake by cells (HoHL and Schopfer 1991, Slama et al. 2007).

Many studies have shown that osmotic stress caused by either use of osmotica or by the withholding of water leads to a reduction in plant RWC which is often accompanied with a decrease of leaf FW or DW (Fu and Huang 2001, Egert and Tevini 2002, Slama et al. 2007). However, in our study, DW of F. triquetra shoots significantly increased under both mannitol and PEG treatment. Similar results with respect to DW and RWC were obtained with drought-tolerant bean cultivar Phaseolus acutifolius grown on the medium with PEG for a 14-day period (TÜRKAN et al. 2005). The increase in DW of stressed plants noted in our study could, at least partly, be ascribed to increased accumulation of proline. However, regarding the level of proline accumulation in osmotically stressed F. triquetra shoots, especially under mannitol, the observed increase in DW might be the result of increased synthesis of other organic compounds which are used in osmotic adjustment (HARE et al. 1998, SLAMA et al. 2007, FAROOQ et al. 2009) or different proteins such as HSP proteins and dehydrins engaged in the adaptation to abiotic stress (WANG et al. 2004). A rise in proline noted in our study was too low to suggest that the amino acid acts as an osmolyte (Slama et al. 2007). Thus, it is likely that proline accumulation in F. triquetra shoots is related to some other proline roles such as ROS detoxification, protection of cellular macromolecules or maintenance of cellular $\mathrm{pH}$. The greater accumulation of proline in response to PEG than to mannitol, described here in response to osmotic stress, has also been observed in osmotically stressed rice (PANDEY et al. 2004).

The tolerance to drought may be closely related with efficient photoprotective system (FAROOQ et al. 2009). In the present study, dynamics of changes in chlorophyll and carotenoid contents of stressed $F$. triquetra over time was similar - the pigments showed an initial rise, chlorophyll $a$ and carotenoids were still elevated under PEG-stress after 7 day-period while after 14 day-period the levels of those pigments also leveled with control ones. Increased or unaffected levels of chlorophylls and carotenoids under osmotic stress imply a better photoprotection and capacity for light harvesting and are considered to be a defensive response which restricts the harmful effects of drought (FAROOQ et al. 2009). Similar results with respect to chlorophyll and carotenoid levels had been reported in drought-tolerant plant species exposed to drought stress conditions (Fu and HuANg 2001, EgerT and TEVIni 2002, Kalefetoglu Macer and EKMeKCI 2009).

The results presented here indicate that osmotic stress increased antioxidative defense in F. triquetra shoots, especially in the case of PEG. However, regarding parameters of oxidative injury to vital biomolecules, F. triquetra proved to be less susceptible to mannitol- 
than to PEG-induced osmotic stress. The indicator of lipid peroxidation, MDA, after initial increase under both mannitol and PEG treatment, remained at high levels only in PEGstressed plants. The high-molecular PEG also caused transient increase in carbonyl groups content indicating oxidative damage to proteins. The results suggest far greater ROS production under PEG- than mannitol-stress despite the relatively higher induction of antioxidative defense in response to PEG. Concerning chlorophyll and carotenoid contents under PEG-stress, the targets for harmful action of ROS might not necessarily be thylakoid membranes but possibly other ROS-generating sites like mitochondria, plasma membranes, cell wall etc. (MorAn et al. 1994). Several plant species exposed to PEG-induced osmotic stress showed the same pattern of change in $\mathrm{MDA}, \mathrm{C}=\mathrm{O}$ groups and the activities of antioxidative enzymes described here i.e. the increase in the extent of lipid peroxidation or protein carbonylation with simultaneous induction of antioxidative enzymes upon PEG action (SIVRITEPE et al. 2008, PyNGROPE et al. 2013).

SOD, an enzyme that breaks down superoxide radicals to hydrogen peroxide and oxygen, is often activated in response to osmotic stress especially in plants tolerant to the stress conditions (Bor et al. 2003, TÜRKAN et al. 2005, HuANG et al. 2013, RADIĆ et al. 2013). SOD activity in shoots of treated plants $F$. triquetra increased after 14 days of the experiment which indicates that this species is well adapted to the conditions of osmotic stress and can activate the mechanism of elimination of superoxide radicals. Hydrogen peroxide requires further degradation enabled by the plant APOX, non-specific peroxidase (POX) and CAT. Two enzymes engaged in the decomposition of hydrogen peroxide were induced in the $F$. triquetra shoots, though in some plant species, depending on the type and severity of stress, an increased activity of only one enzyme can be apparent. The main enzyme for degrading $\mathrm{H}_{2} \mathrm{O}_{2}$ in chives and Centaurea ragusina leaves exposed to osmotic stress was APOX (EGERT and TEVIni 2002, Radić et al. 2013) while in pea plants exposed to drought it was nonspecific peroxidase (MorAn et al. 1994). In our study, the activities of peroxidases, rather than activity of CAT, seem to have a major role in the degradation of hydrogen peroxide produced upon osmotic stress. On the other hand, osmotic stress in cherry rootstock caused activation of all three $\mathrm{H}_{2} \mathrm{O}_{2}$-degrading enzymes (SivRITEPE et al. 2008).

A number of different proteins, including HSP proteins, are synthesized or accumulated in response to osmotic stress (RIZHSKY et al. 2002). Studies on Arabidopsis and spinach demonstrated that over-expression of HSP70 chaperones results in enhanced tolerance to salt, water and high-temperature stress in plants (WANG et al. 2004). In our study, accumulation of HSP70 in F. triquetra exposed to mannitol and PEG was evident after a period of only $24 \mathrm{~h}$. Similar results with respect to expression of HSP70 were obtained in Fucus serratus and Lemna minor upon osmotic stress conditions (IRELAND et al. 2004).

In conclusion, both osmotica, especially PEG, caused oxidative stress in $F$. triquetra, but also a rapid activation of antioxidant and protective defense mechanisms (enzymatic and non-enzymatic antioxidants, accumulation of HSP70). Based on the results and previous findings on the plant's morphology, it can be concluded that F. triquetra is relatively tolerant to osmotic stress due to inducible defense systems.

\section{Acknowledgements}

This study was supported by Croatian Ministry of Science, Education and Sport, as part of Project no. 119-1191196-1202. 


\section{References}

Aebi, H., 1984: Catalase in vitro. Methods in Enzymology 105, 121-126.

Bartels, D., Sunkar, R., 2005: Drought and salt tolerance in plants. Critical Reviews in Plant Sciences 24, 23-58.

Bates, L. S., Waldren, R. P., Teare, I. D., 1973: Rapid detremination of free proline for water stress studies. Plant and Soil 39, 205-207.

Bor, M., ÖZDEMIR, F., TÜRKAN, I., 2003: The effect of salt stress on lipid peroxidation and antioxidants in leaves of sugar beet Beta vulgaris L. and wild beet Beta maritima L. Plant Science 164, 77-84.

BRADFORD, M. M., 1976: A rapid and sensitive method for the quantitation of microgram quantities of protein utilizing the principle of protein-dye binding. Analytical Biochemistry $72,248-254$.

Chance, B., Maehly, A. C., 1955: Assay of catalases and peroxidases. In: Colowick S. P. and Kaplan N. O. (eds.) Methods in Enzymology, 764-775. Academic Press, New York.

Chaves, M. M., Flexas, J., Pinheiro, C., 2009: Photosynthesis under drought and salt stress: regulation mechanisms from whole plant to cell. Annals of Botany 103, 551-560.

Chazen, O., Hartung, W., Neumann, P. M., 1995: The different effects of PEG 6000 and $\mathrm{NaCl}$ on leaf development are associated with differential inhibition of root water transport. Plant, Cell and Environment 18, 727-735.

Cruz De Carvalho, M. H., 2008: Drought stress and reactive oxygen species: production, scavenging and signaling. Plant Signaling and Behavior 3, 156-165.

Egert, M., Tevini, M., 2002: Influence of drought on some physiological parameters symptomatic for oxidative stress in leaves of chives (Allium schoenoprasum). Environmental and Experimental Botany 48, 43-49.

Farooq, M., Wahid, A., Kobayashi, N., Fujita, D., Basra, S. M. A., 2009: Plant drought stress: effects, mechanisms and management. Agronomy for Sustainable Development 29, $185-212$.

Fu, J., HuAnG, B., 2001: Involvement of antioxidants and lipid peroxidation in the adaptation of two cool-season grasses to localized drought stress. Environmental and Experimental Botany 45, 105-114.

Giannopolitis, C. N., Ries, S. K., 1977: Superoxide dismutase. I. Occurrence in higher plants. Plant Physiology 59, 309-314.

Hare, P. D., Cress, W. A., Van Staden, J., 1998: Dissecting the roles of osmolyte accumulation during stress. Plant, Cell and Environment 21, 535-553.

Hayat, S., Hayat, Q., Alyemeni, M. N., Wani, A. S., Pichtel, J., Ahmad, A., 2012: Role of proline under changing environments: a review. Plant Signaling and Behavior 7, 1456-1466.

Heath, R. L., Packer, L., 1968: Photoperoxidation in isolated chloroplasts. I-kinetics and stoichiometry of fatty acid peroxidation. Archives of Biochemistry and Biophysics 125 , 189-198.

Hohl, M., Schopfer, P., 1991: Water relations of growing maize coleoptiles. Comparison between mannitol and polyethylene glycol 6000 as external osmotica for adjusting turgor pressure. Plant Physiology 95, 716-722. 
Huang, C., Zhao, S., Wang, L., Anuum, S. A., Chen, M., Zhou, H., Zou, C., 2013: Alteration in chlorophyll fluorescence, lipid peroxidation and antioxidant enzymes activities in hybrid Ramie (Boehmeria nivea L.) under drought stress. Australian Journal of Crop Science 7, 594-599.

Ireland, E. H., Harding, S. J., Bonwick, G. A., Jones, M., Smith, C. J., Williams, J. H., 2004: Evaluation of heat shock protein 70 as a biomarker of environmental stress in Fucus serratus and Lemna minor. Biomarkers 9, 139-155.

Kalefetoglu Macar, T., Ekmekci, Y., 2009: Alterations in photochemical and physiological activities of chickpea (Cicer arietinum L.) cultivars under drought stress. Journal of Agronomy and Crop Science 195, 335-346.

Levine, R. L., Garland, D., Oliver, C. N., Amici, A., Climent, I., Lenz, A. G., Ahn, B. W., Shaltiel, S., Stadtman, E. R., 1990: Determination of carbonyl content in oxidatively modified proteins. Methods in Enzymology 186, 464-478.

Lichtenthaler, H. K., 1987: Chlorophylls and carotenoids: Pigments of photosynthetic membranes. Methods in Enzymology 148, 350-382.

Moran, J. F., Becana, M., Iturbe-Ormaetxe, I., Frechilla, S., Klucas, R. V., Aparico-Tejo, P., 1994: Drought induces oxidative stress in pea plants. Planta 194, 346-352.

Murashige, T., Skoog, F., 1962: A revised medium for rapid growth and bioassays with tobacco tissue cultures. Physiologia Plantarum 15, 473-97.

NAKANO, Y., AsAda, K., 1981: Hydrogen peroxide is scavenged by ascorbate-specific peroxidase in spinach chloroplasts. Plant Cell Physiology 22, 867-880.

Pandey, R., Agarwal, R. M., Jeevaratnam, K., Sharma, G. L. M, 2004: Osmotic stressinduced alterations in rice (Oryza sativa L.) and recovery on stress release. Plant Growth Regulation 42, 79-87.

Pevalek-Kozlina, B., Kostović-Vranješ, V., Slade, D., 1997: In vitro propagation of Fibigia triquetra (DC.) Boiss., a rare stenoendemic species. Plant Cell, Tissue and Organ Culture 51, 141-143.

Pyngrope, S., Bhoomika, K., Dubey R. S., 2013: Oxidative stress, protein carbonylation, proteolysis and antioxidative defense system as a model for depicting water deficit tolerance in Indica rice seedlings. Plant Growth Regulation 69, 149-165.

Radić, S., Peharec Štefanić, P., Lepeduš, H., Roje, V., Pevalek-Kozlina, B., 2013: Salt tolerance of Centaurea ragusina $\mathrm{L}$. is associated with efficient osmotic adjustment and increased antioxidative capacity. Environmental and Experimental Botany 87, 39-48.

Radić, S., Radić-Stojković, M., Pevalek-Kozlina, B., 2006: Influence of NaCl and mannitol on peroxidase activity and lipid peroxidation in Centaurea ragusina L. roots and shoots. Journal of Plant Physiology 163, 1284-1292.

Reddy, A. R., Chaitanya, K. V., Vivekanandan, M., 2004: Drought-induced responses of photosynthesis and antioxidant metabolism in higher plants. Journal of Plant Physiology 161, 1189-1202.

Rizhsky, L., Liang, H., MitTler, R., 2002: The combined effect of drought stress and heat shock on gene expression in tobacco. Plant Physiology 130, 1143-1151.

Sivritepe, N., Erturk, U., Yerlikaya, C., Turkan, I., Bor, M., Ozdemir, F., 2008: Response of the cherry rootstock to water stress induced in vitro. Biologia Plantarum 52, 573576. 
Slama, I., Ghnaya, T., Hessini, K., Messedi, D., Savoure, A., Abdelly C., 2007: Comparative study of the effects of mannitol and PEG osmotic stress on growth and solute accumulation in Sesuvium portulacastrum. Environmental and Experimental Botany 61, $10-17$.

TÜrkan, I., Bor, M., ÖZdemir, F., KocA, H., 2005: Differential response of lipid peroxidation and antioxidants in the leaves of drought-tolerant $P$. acutifolius Gray and droughtsensitive $P$. vulgaris L. subjected to polyethylene glycol mediated water stress. Plant Science 168, 223-231

Verslues, P. E., Agarwal, M., Katiyar-Agarwal, S., Zhu J., Zhu, J.-K., 2006: Methods and concepts in quantifying resistance to drought, salt and freezing, abiotic stresses that affect plant water status. The Plant Journal 45, 523-539.

Wang, W., Vinocur, B., Shoseyov, O., Altman, A., 2004: Role of plant heat-shock proteins and molecular chaperones in the abiotic stress response. Trends in Plant Science 9, 244 252.

Xiong, L., Zhu J. K., 2002: Molecular and genetic aspects of plant responses to osmotic stress. Plant, Cell and Environment 25, 131-139. 